Primljen / Received: 20.6.2013. Ispravljen / Corrected: 30.10.2013.

Prihvaćen / Accepted: 14.12.2013. Dostupno online / Available online: 10.2.2014.

\section{Hydro-abrasive resistance and mechanical properties of rubberized concrete}

\section{Authors:

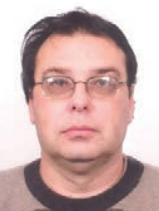 \\ Prof. Zoran Grdić \\ University of Nis \\ Faculty of Civil Eng. and Arch. zoran.grdic@gaf.ni.ac.rs}

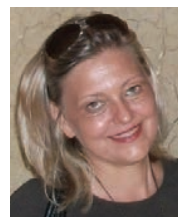

Assist.Prof. GordanaTopličić-Ćurčić University of Nis

Faculty of Civil Eng. and Arch. gordana.toplicic.curcic@gaf.ni.ac.rs

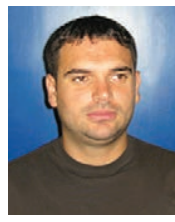

MSc. Nenad Ristić University of Nis Faculty of Civil Eng. and Arch. nenad.ristic@gaf.ni.ac.rs

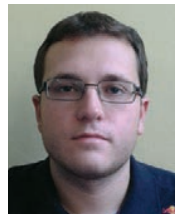

MSc. Dušan Grdić University of Nis Faculty of Civil Eng. and Arch. dusan.grdic@hotmail.rs

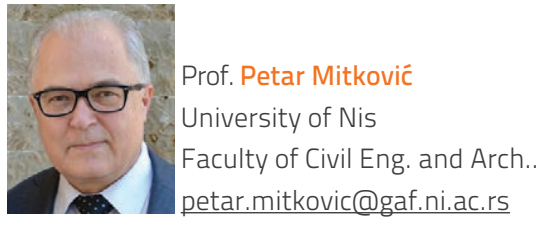

\section{Zoran Grdić, Gordana Topličić-Ćurčić, Nenad Ristić, Dušan Grdić, Petar Mitković}

\section{Hydro-abrasive resistance and mechanical properties of rubberized concrete}

Results obtained by testing hydro-abrasive resistance and mechanical properties of concrete with rubber granules are presented in the paper. Fine river aggregate is replaced with 10,20, and 30 percent of recycled granulated rubber (with respect to the total volume). Research results demonstrate that replacement of fine river aggregate by granulated rubber increases hydro-abrasive resistance of concrete by up to 10 percent. The replacement of fine river aggregate by rubber increases the energy dissipation capacity and ductility.

\section{Key words:}

hydro-abrasive resistance, concrete, recycled rubber, accelerated test, mechanical properties

Prethodno priopćenje

Zoran Grdić, Gordana Topličić-Ćurčić, Nenad Ristić, Dušan Grdić, Petar Mitković

\section{Otpornost na hidroabraziju i mehanička svojstva betona s dodatkom gume}

U radu su prikazani rezultati ispitivanja hidroabrazivne otpornosti i mehaničkih svojstava betona s dodatkom gumenih granula. Sitni riječni agregat zamijenjen je s 10, 20 i 30 posto reciklirane granulirane gume (u odnosu na ukupan volumen). Rezultati ispitivanja pokazuju da zamjenom sitnog riječnog agregata granuliranom gumom dolazi do povećanja hidroabrazivne otpornosti betona do 10 posto. Zamjena sitnog riječnog agregata gumenim materijalom dovodi do povećanja sposobnost raspodijele energije i duktilnosti.

Ključne riječi:

hidroabrazivna otpornost, beton, reciklirana guma, ubrzano ispitivanje, mehanička svojstva

\section{Vorherige Mitteilung}

\section{Zoran Grdić, Gordana Topličić-Ćurčić, Nenad Ristić, Dušan Grdić, Petar Mitković}

\section{Hydro-Abriebfestigkeit und mechanischen Eigenschaften von Beton mit Gummigranulat}

In der vorliegenden Arbeit sind Resultate von Messungen der Hydro-Abriebfestigkeit und der mechanischen Eigenschaften von Beton mit Gummigranulat dargestellt. Feines Betonaggregat ist durch rezykliertes Gummigranulat in einen Anteil von $10 \%$, $20 \%$ und $30 \%$ des Gesamtvolumens ersetzt worden. Die Resultate zeigen, dass durch den Austausch von Betonaggregat mit Gummigranulat die Hydro-Abriebfestigkeit des Betons bis zu $10 \%$ ansteigt. Außerdem steigen durch das Ersetzen des Betonaggregats mit Gummigranulat sowohl die Energiedissipationskapazität als auch die Duktilität an. 


\section{Introduction}

Large quantities of waste materials or industrial by-products are presently used thanks to recent advancements in concrete technology. They can be used as mineral admixtures or as filler-aggregates, for partial or full replacement of natural stone aggregate [1-3]. Waste car tires have become a worldwide environmental problem. Shredded, chipped, granulated, or crumb rubber is made in the scope of recycling processes, and then possibilities for using such rubber as partial replacement of concrete aggregate is evaluated. The use of recycled rubber in the production of concrete is important for two reasons: direct use of waste material is important for environmental reasons while enhancement of physico-mechanical properties of concrete is important for structural reasons.

Many tests have been carried out on concrete with varying volume/share of replacement of stone aggregate with granulated rubber. In their research [4], Issa and Salem replaced crushed sand by granulated rubber using 15, 25, 50, and 100 percent of rubber. By analysing results obtained by testing physicomechanical characteristics of concrete, they found out that concrete which has up to $25 \%$ of fine aggregate substituted by rubber can be applied in the production of loadbearing structural elements. In their paper [5], Sukontasukkul and Tiamlom replaced aggregate with 10, 20 and 30 percent of rubber. They concluded that the concrete shrinkage increases with an increase of rubber content in concrete. In their research, Al-Tayeb et al. [6] and Ozbay et al. [7] replaced fine aggregate with 5, 10 and 20 percent, and 5, 15 and 20 percent of rubber, respectively. It was established by testing that the concrete strength and static modulus of elasticity values decrease with an increase in rubber content. It was also established that the concrete resistance to impact and energy dissipation capacity increases with an increase in rubber content. In their paper [8], Gesoglu and Guneyisi replaced aggregate with 5, 15, and 25 percent of rubber, and concluded that the increase in the share of rubber brings about an increase in the chloride ion penetration through concrete. In their research [9], Lakusic, Bjegovic et al. used recycled rubber in order to improve mechanical properties and durability of an innovative and environmentally acceptable material for the production of contemporary railways on hard concrete base. They replaced 5 percent of stone aggregate with the recycled granulated rubber and improved in this way the modulus of elasticity, water permeability, and capillary absorption of concrete, while reducing diffusion of chloride through concrete. Also, Bjegovic et al. asserted in paper [10] that the recycled rubber increases ductility, resistance to wear and impact load of concrete. In their paper [11], Serdar et al. used, among other materials, rubber granules for construction of noise barriers. In addition to good absorption capacity (absorption class A3), the barrier exhibited good resistance to frost and fire. In general, concrete prepared with crumb rubber exhibits better resistance to dynamic load [12], impacts [6], cracking, noise reduction [13], and is characterized by low heat conductivity and flexibility during thermal expansion and contraction due to its ductile behaviour. Since the addition of granulated rubber to concrete results in the reduction of concrete strength, the choice of replacement rubber content is very important for obtaining concrete with high durability properties in service conditions.

The abrasive wear of concrete in hydraulic structures is most often caused by the action of water-borne particles (silt, sand, gravel and other solid particles), which erode concrete surface through hydraulic processes. This abrasive-erosive concrete damage is an important issue in the maintenance of hydraulic structures, and this process must be taken into account when designing such structures and choosing appropriate concrete mixtures. The order of magnitude of damage is usually several centimetres, but the damage can be much greater after no more than several years of abrasive action. Although weak abrasive-erosive activity does not constitute a big problem, very pronounced activity may endanger structural integrity of concrete, as well as functionality of the structure [14]. The protection of hydraulic structures made of concrete against abrasive-erosive activity can be achieved by using durable concrete mixtures resistant to abrasion-erosion.

Recommendations are given for the design of concrete mixes that will be resistant to hydro-abrasive action [15]. In this respect, it is suggested to use the hardest aggregate available, low water-cement ratios, powerful water reducers, powdery mineral admixtures such as silica fume, etc. Apart from composition of concrete mixture, the resistance of concrete to abrasive action is also dependent on external conditions to which concrete is exposed. The research conducted by various authors shows that the concrete produced with various mineral admixtures (silica powder, fly ash, blast furnace slag, milled basalt) [16-20], with the addition of still fibres [21-24], and polypropylene fibres [25-26], or with aluminate cement, high strength concrete, rolled concrete, and addition of recycled granulated rubber [27-28], have to a smaller or greater extent a better abrasive resistance in comparison with reference concrete produced without any admixtures, with the common Portland cement.

The concrete used for construction of hydraulic structures, which is in direct contact with water, apart from having good mechanical properties, must also be resistant to hydro-abrasion. Many tests showed that mechanical characteristics of concrete can be used to predict its hydro-abrasive resistance. Siddique and Khatib, Yen et al., Lui Y.W. et al. [18, 29-30] showed that there is a correlation between the abrasive resistance of concrete, and the compressive strength and flexural strength. In his paper [28], Šušterčič showed that the concrete with 9.5 percent replacement granulated rubber instead of fine river aggregate, has a better hydro-abrasive strength in comparison with the reference concrete with no rubber. He also showed that there is a strong connection between hydro-abrasive resistance of concrete on the one hand, and compressive strength, modulus of elasticity, and wear resistance by Böhme, on the other.

The choice of testing methodology for the determination of concrete resistance to abrasive wear is very important. The erosion of concrete used on hydraulic structures is a long- 
term process, and it usually develops over a period of several months, although sometimes even years can pass before the damage can be observed. This is why accelerated concrete abrasion methods are necessary. Several studies, performed on the basis of accelerated tests, have so far been published. Most equipment for testing abrasive resistance of concrete that has been described in professional literature is based on simulation of sand blasting mechanisms [31-33] and grooving with dry friction [34-36]. Many papers [37-39] and test methods according to ASTM standards [40] describe research performed under conditions similar to natural environment, using equipment that allows a concrete abrasion process, based on aggregate and water mixture model. Momber and Kovacevic [41] have also applied the accelerated water jet test method for testing hydraulic wear of concrete. For solving the problems in this study, the method of abrasive water jet could be applied for a very rapid wear of concrete by the mixture of water and solid particles moving at high velocity.

Effects of replacement of fine aggregate by the recycled granulated rubber on physicomechanical characteristics and hydro-abrasive resistance of concrete are studied in this paper.

\section{Details of the experiment}

\subsection{Materials used in the experiment}

The reference concrete was produced with the Portland cement CEM I $42.5 \mathrm{R}$, whose properties are presented in the Table 1.

Table 1. Physicomechanical properties of cement according to SRPS EN 196-1:2008 and SRPS EN 196-3:2010

\begin{tabular}{|l|c|}
\hline Property of cement & Value \\
\hline Setting time & $\begin{array}{c}\text { start } 135 \mathrm{~min} \\
\text { end } 160 \mathrm{~min}\end{array}$ \\
\hline Mill fineness- sieve residue $0.09 \mathrm{~mm}$ & $3,2 \%$ \\
\hline Density & $3000 \mathrm{~kg} / \mathrm{m}^{3}$ \\
\hline Loose material bulk density & $925 \mathrm{~kg} / \mathrm{m}^{3}$ \\
\hline Compacted material bulk density & $1521 \mathrm{~kg} / \mathrm{m}^{3}$ \\
\hline Bending strength at 2 days & $5,99 \mathrm{~N} / \mathrm{mm}^{2}$ \\
\hline Bending strength at 28 days & $7,21 \mathrm{~N} / \mathrm{mm}^{2}$ \\
\hline Compressive strength at 2 days & $33,67 \mathrm{~N} / \mathrm{mm}^{2}$ \\
\hline Compressive strength at 28 days & $54,21 \mathrm{~N} / \mathrm{mm}^{2}$ \\
\hline
\end{tabular}

The aggregate obtained by mixing three fractions $(0 / 4,4 / 8$, and $8 / 16 \mathrm{~mm}$ ) of river aggregate from the Southern Morava River was used for preparation of concrete. Particle size distribution of individual fractions, and aggregate mixtures used, are presented in the Figure 1.

The recycled rubber used was a $0.5-4 \mathrm{~mm}$ fraction. The particle density and bulk density of rubber aggregate in the loose state were determined according to SRPS ISO 6783:1999 and SRPS ISO 6782:1999, and they amounted to $1150 \mathrm{~kg} / \mathrm{m}^{3}$ and $480 \mathrm{~kg} / \mathrm{m}^{3}$, respectively. The particle size distribution of granulated recycled rubber is presented in Figure 1. The superplasticising water reducer was also used.

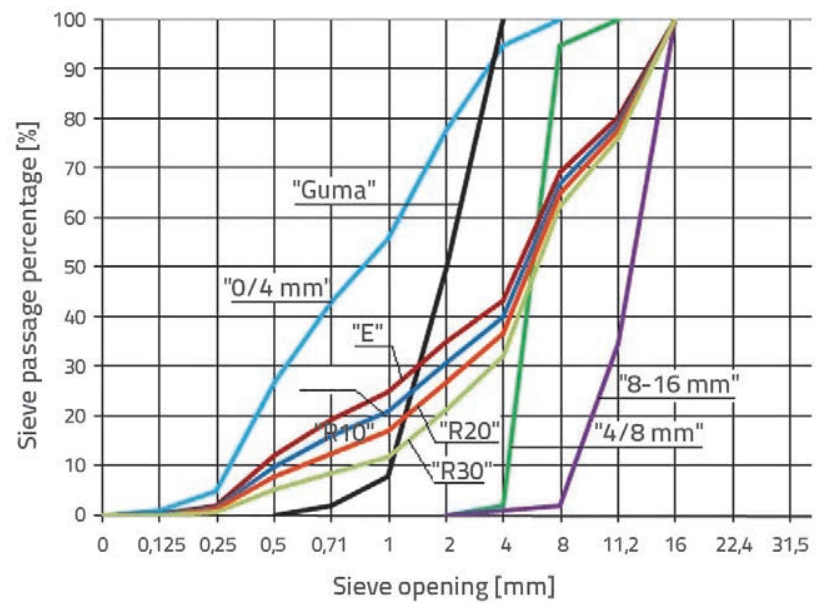

Figure 1. Particle size distribution of the individual fractions and aggregate mixtures used

\subsection{Composition of concrete mixture}

Four mixtures were prepared for testing properties of fresh and hardened concrete. The reference mixture was prepared with the river aggregate, cement, water, and water reducer, marked with $\mathrm{E}$. Three mixtures in which the river aggregate was partly replaced with recycled rubber granulate were also prepared. The aggregate substitution was performed by volume. The mixture marked R10 was made with $10 \%$ of rubber substitute, R20 with $20 \%$ of rubber substitute, and R30 with $30 \%$ of rubber substitute. The mixtures were made with the same water /cement ratio $\omega_{c}=0.42$ and with approximately the same consistency of concrete (slump 90 - $110 \mathrm{~mm}$ ) which was achieved using the superplasticiser. Concrete mix compositions are given in Table 2.

Table 2. Composition of $1 \mathrm{~m}^{3}$ of concrete mixtures used in the experiment

\begin{tabular}{|c|c|c|c|c|c|c|c|c|c|c|c|}
\hline \multirow{3}{*}{$\begin{array}{l}\text { Specimen } \\
\text { series }\end{array}$} & \multicolumn{6}{|c|}{ Aggregate } & \multirow{2}{*}{\multicolumn{2}{|c|}{$\begin{array}{l}\text { Rubber } \\
1 / 4 \mathrm{~mm}\end{array}$}} & \multirow{3}{*}{$\begin{array}{c}\text { Cement } \\
\text { [kg] }\end{array}$} & \multirow{3}{*}{$\begin{array}{c}\text { Water } \\
\text { [kg] }\end{array}$} & \multirow{3}{*}{$\begin{array}{c}\text { Superplasticiser } \\
{[\mathrm{kg}]}\end{array}$} \\
\hline & \multicolumn{2}{|c|}{$0 / 4 \mathrm{~mm}$} & \multicolumn{2}{|c|}{$4 / 8 \mathrm{~mm}$} & \multicolumn{2}{|c|}{$8 / 16$ mm } & & & & & \\
\hline & {$[\%]$} & {$[\mathrm{kg}]$} & {$[\%]$} & {$[\mathrm{kg}]$} & {$[\%]$} & {$[\mathrm{kg}]$} & {$[\%]$} & {$[\mathrm{kg}]$} & & & \\
\hline$E$ & 45 & 810 & 25 & 450 & 30 & 540 & - & - & 400 & 168 & 3,20 \\
\hline R10 & 35 & 638 & 25 & 456 & 30 & 547 & 10 & 64 & 405 & 170 & 3,65 \\
\hline R2O & 26 & 465 & 25 & 450 & 30 & 540 & 20 & 126 & 400 & 168 & 4,00 \\
\hline R30 & 16 & 290 & 25 & 456 & 30 & 547 & 30 & 189 & 405 & 168 & 4,40 \\
\hline
\end{tabular}



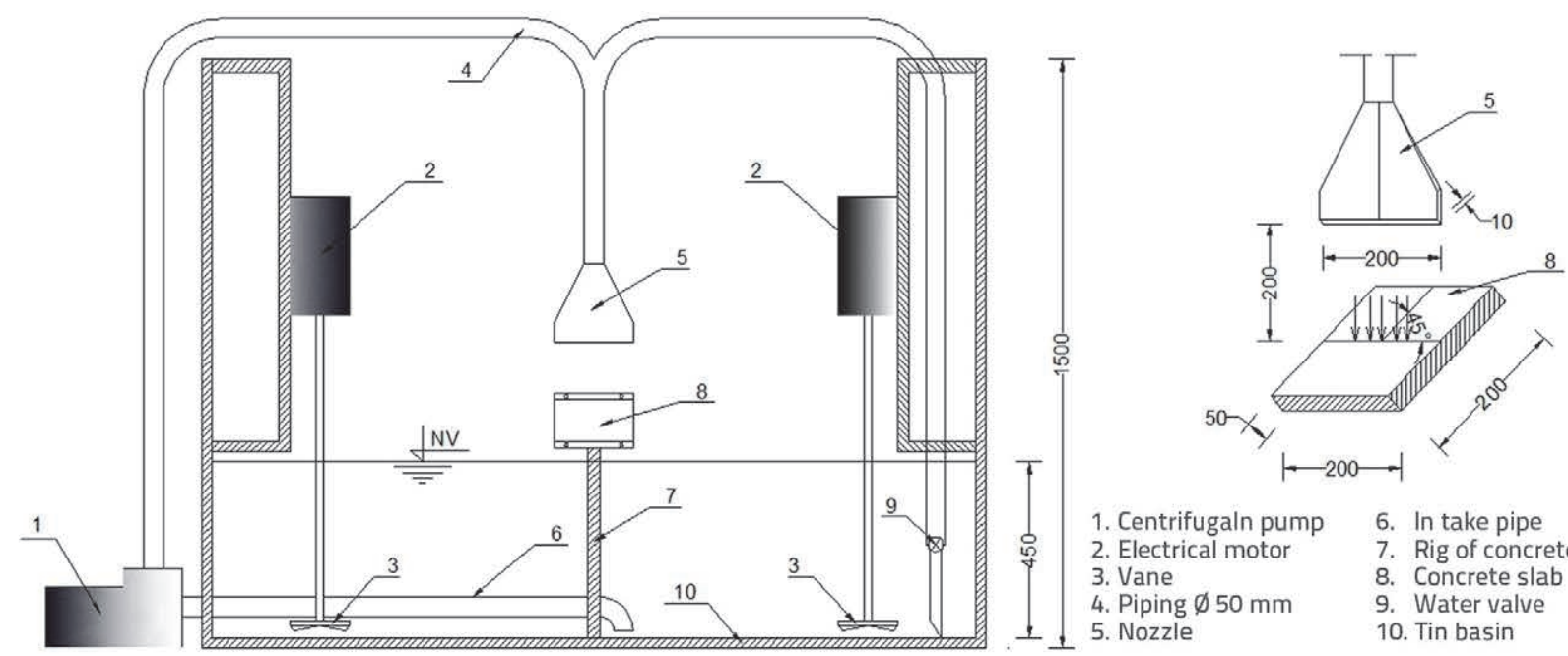

6. In take pipe

7. Rig of concrete slab

8. Concrete slab

9. Water valve

10. Tin basin

Figure 2. Schematic drawing of equipment for testing abrasion of concrete

\section{Experimental research}

The test of the hydro-abrasive resistance of concrete was conducted using the original equipment constructed in the Building Materials Laboratory of the Faculty of Civil Engineering and Architecture of Nis. The schematic diagram of the equipment for concrete abrasion resistance testing is presented in Figure 2. Similar equipment was used by researchers in Taiwan for testing abrasive resistance of concrete $[17,30]$.

The equipment consists of a tin basin measuring 2,0 x 2,0 m at the base, and $1,5 \mathrm{~m}$ in height. Its front side covered with a transparent Plexiglas panel enabling visual observations during the test. For the testing, the basin is filled up to one third of its height with the mixture of water and sand, with granulation from $0.6 \mathrm{~mm}$ to $1.2 \mathrm{~mm}$, at the mass ratio of 10:1. The sand used as the abrasive for concrete wear is silica sand. Four electrical motors turn the vanes thus making a homogenous mixture of water and sand, while the centrifugal pump sucks in the mixture via an intake, and then ejects it under pressure though a nozzle on the test concrete slab measuring $200 \times 200 \times 50 \mathrm{~mm}$. The concrete slab is fitted onto the rig which can rotate about the horizontal axis and in this manner change the incidence angle of the jet and the examined specimen.

The test specimen, i.e. concrete slab, is first dried to the constant mass at $105 \pm 5{ }^{\circ} \mathrm{C}$, and the mass is then measured $\left(m_{1}\right)$. After that, the specimen is saturated with water via the gradual immersion method, and exposed to the action of the water/sand mixture jet for the period of 120 minutes. The water temperature during the test is $30^{\circ} \mathrm{C}$. Eventually, the specimen is dried once again to the constant mass and then the mass of abraded specimen $\left(m_{2}\right)$ is measured. The accuracy of the specimen mass measurement is $\pm 0,1 \mathrm{~g}$. The water/ sand mixture jet acts on the concrete test slab surface at the angle of $45^{\circ}$ via the rectangular jet nozzle measuring $10 \times 200$ $\mathrm{mm}$. The nozzle jet velocity is $20 \mathrm{~m} / \mathrm{s}$, which is equivalent to the pressure of 2.4 bars or 0,24 MPa. Since the velocity, that is, the jet pressure at the nozzle was higher in this test than in the test performed by Lui et al. $[17,30]$, the test duration is shorter, and amounts to 120 minutes. The mass difference $\Delta \mathrm{m}$ is the mass of the material abraded under the action of the abrasive suspended in water. The abrasion erosion rate $\mathrm{E}_{\mathrm{R}, \mathrm{m}}$ by mass is calculated as:

$$
\mathbf{E}_{\mathrm{R}, \mathrm{m}}=\frac{\Delta \mathbf{m}}{\mathbf{t}}=\frac{\mathbf{m}_{1}-\mathbf{m}_{2}}{\mathbf{t}}[\mathrm{g} / \mathrm{min}]
$$

where:

$m_{1}$ and $m_{2}-$ masses of the specimen dried to the constant mass before and after the action of the mixture of water and abrasive.

t - time in which the mixture acts on the test sample ( $t=120 \mathrm{~min}$ ).

The concrete density reduces considerably with an increase in the content of recycled rubber. It is more efficient to observe the change of sample volume prior to and after the test, so as to enable better understanding of the damage sustained during hydro-abrasive wear. The sample volume change is determined according to the following formula

$\Delta \mathbf{V}=\frac{\Delta \mathbf{m}}{\gamma_{\text {hard,conc }}}\left[\mathrm{cm}^{3}\right]$

i.e., the abrasion erosion rate by volume

$\mathbf{E}_{\mathrm{R}, \mathrm{V}}=\frac{\Delta \mathbf{V}}{\mathbf{t}}=\frac{\frac{\mathbf{m}_{1}-\mathbf{m}_{2}}{\gamma_{\text {hard.conc }}}}{\mathbf{t}} \quad\left[\mathrm{cm}^{3} / \mathrm{min}\right]$

where:

$\gamma_{\text {hard,conc }}-$ density of hardened concrete, dried to the constant mass in $\mathrm{g} / \mathrm{cm}^{3}$ determined according to SRPS EN 12390-7:2010. 
Table 3. Accompanying tests conducted in the scope of this research

\begin{tabular}{|l|l|}
\hline Test type & Standard \\
\hline Consistency of fresh concrete & SRPS EN 12350-2:2010: Testing fresh concrete - Part 2: Slump-test \\
\hline Density of fresh concrete & SRPS EN 12350-6:2010: Testing fresh concrete - Part 6: Density \\
\hline Compressive strength & SRPS ISO 4012:2000: Concrete - Determination of compressive strength of test specimens \\
\hline Flexural strength & SRPS ISO 4013:2000: Concrete - Determination of flexural strength of test specimens \\
\hline Determination of rebound number & $\begin{array}{l}\text { SRPS EN 12504-2:2008: Testing concrete in structures - Part 2: Non-destructive testing - } \\
\text { Determination of rebound number }\end{array}$ \\
\hline Determination of ultrasonic pulse velocity & SRPS EN 12504-4:2008: Testing concrete - Part 4: Determination of ultrasonic pulse velocity \\
\hline Determination of static modulus of elasticity & SRPS ISO 6784:2000: Concrete - Determination of static modulus of elasticity in compression \\
\hline Measurement of bond strength by pull-off & EN 1542:1999: Product and system for the protection and repair of concrete structures - \\
\hline
\end{tabular}

The damage sustained by Böhme grinding wear is determined in a similar way. For every type of concrete, the hydro-abrasive resistance is tested on three samples.

The accompanying tests of hardened and fresh concrete were performed on samples of appropriate form and number, according to prevailing SRPS and EN standards, Table 3. All tested samples were made from the same mix of each type of concrete. Bond strength tests using the "pull-off" method deviate from the standard method in that the incision depth with the drill $\varnothing 50$ was $5 \mathrm{~mm}$, while the provisions of the previously mentioned standard require the incision depth of $15 \pm 5 \mathrm{~mm}$. The age of samples at the hardened concrete testing was 28 days.

\section{Experimental study results and discussion}

Tests results for fresh and hardened concrete are presented in Tables 4, 5 and 6. These test results are presented as mean values of individual measurements, obtained on the basis of an appropriate number of samples prescribed by the standard. There is no pronounced dissipation of individual mean value measurement results. For instance, deviation of individual

Table 4. Characteristics of fresh concrete

\begin{tabular}{|c|c|c|c|}
\hline $\begin{array}{c}\text { Specimen } \\
\text { series }\end{array}$ & $\begin{array}{c}\text { Density } \\
{\left[\mathrm{kg} / \mathrm{m}^{3}\right]}\end{array}$ & $\begin{array}{c}\text { Slump } \\
\text { class }\end{array}$ & $\begin{array}{c}\text { Air content } \\
{[\%]}\end{array}$ \\
\hline $\mathrm{E}$ & 2375 & $\mathrm{~S} 3(110 \mathrm{~mm})$ & 3,1 \\
\hline R10 & 2285 & $\mathrm{~S} 3(100 \mathrm{~mm})$ & 3,5 \\
\hline R20 & 2155 & $\mathrm{~S} 2(90 \mathrm{~mm})$ & 5,2 \\
\hline R30 & 2060 & $\mathrm{~S} 3(100 \mathrm{~mm})$ & 7,2 \\
\hline
\end{tabular}

Table 5. Characteristics of concrete in hardened state at 28 days

\begin{tabular}{|c|c|c|c|c|c|c|c|}
\hline $\begin{array}{c}\text { Specimen } \\
\text { series }\end{array}$ & $\begin{array}{c}\text { Density } \\
{\left[\mathrm{kg} / \mathrm{m}^{3}\right]}\end{array}$ & $\begin{array}{c}\text { Compressive } \\
\text { strength } \\
{[\mathrm{MPa}]}\end{array}$ & $\begin{array}{c}\text { Flexural } \\
\text { strength } \\
{[\mathrm{MPa}]}\end{array}$ & $\begin{array}{c}\text { Rebound } \\
\text { number }\end{array}$ & $\begin{array}{c}\text { Ultrasonic } \\
\text { pulse velocity } \\
{[\mathrm{m} / \mathrm{s}]}\end{array}$ & $\begin{array}{c}\text { Static modulus } \\
\text { of elasticity } \mathrm{E}_{\mathrm{s}} \\
{[\mathrm{GPa}]}\end{array}$ & $\begin{array}{c}\text { Bond strength } \\
\text { by pull-off } \\
{[\mathrm{MPa}]}\end{array}$ \\
\hline $\mathrm{E}$ & 2370 & 62,89 & 6,48 & 48,23 & 4733 & 32,0 & 2,47 \\
\hline R10 & 2260 & 40,22 & 5,18 & 44,47 & 4479 & 26,8 & 2,11 \\
\hline R20 & 2145 & 25,22 & 4,25 & 38,31 & 4073 & 17,3 & 1,72 \\
\hline R30 & 2057 & 18,56 & 2,90 & 34,72 & 3726 & 14,6 & 1,21 \\
\hline
\end{tabular}

compressive strength values from the mean value amounts to $\pm 3 \%$ for samples marked "E", $\pm 4 \%$ for samples "R10", $\pm 5 \%$ for samples "R20", and $\pm 5 \%$ for samples "R30". Similar results have been obtained for other concrete properties.

Based on test results presented in Tables 4 and 5, it can be concluded that substitution of river aggregate by the recycled rubber granulate in concrete causes significant changes in concrete performance, both in fresh and hardened state. For fresh concrete, it can be observed that the density decreases with an increase in the recycled rubber content, and this in the range from 90 to $315 \mathrm{~kg} / \mathrm{m}^{3}$, i.e. from 4 to $13 \%$. Also, the content of entrained air in concrete increases with an increase in the rubber aggregate content, which is why the plasticizer had to be added in order to keep consistency in the range of 90 to $110 \mathrm{~mm}$.

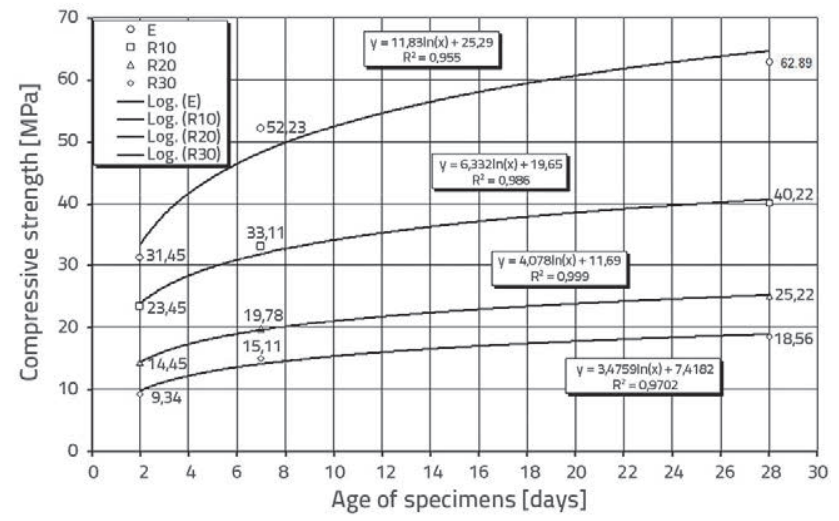

Figure 3. Compressive strength in the function of concrete age 
The observed decrease in density of hardened concrete with an increase of rubber granulate content, of the same order of magnitude as in the fresh concrete, was quite logical. Compressive and flexural strength values decrease to a great extent as the quantity of rubber granulate increases, at various ages of concrete samples, cf. Figures 3 and 4 . The compressive strength decrease of

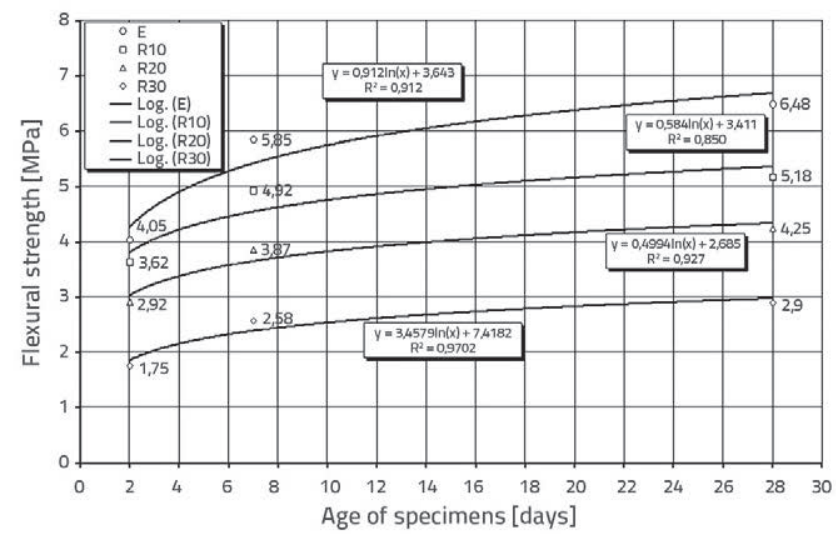

Figure 4. Flexural strength as a function of concrete age
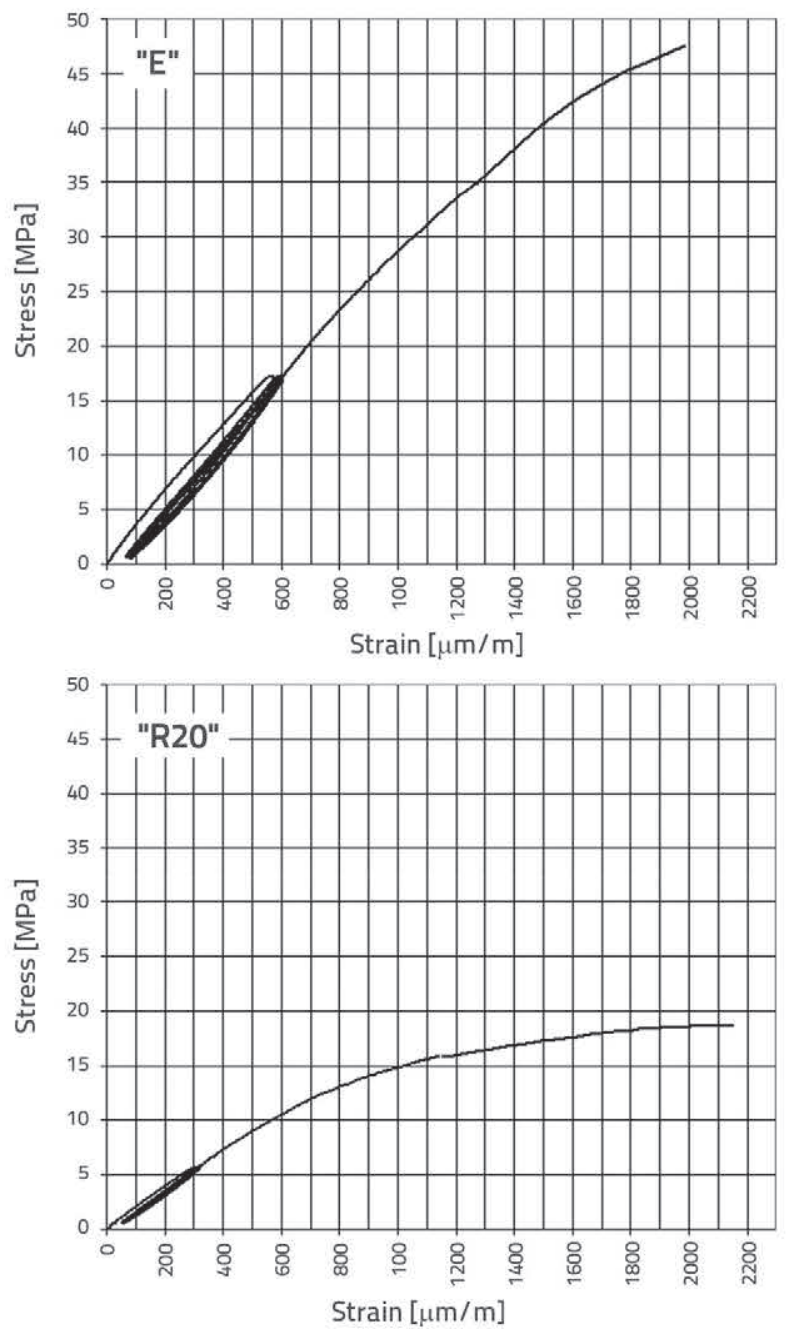

Figure 5. Stress - strain diagram at the static elastic modulus testing 28-day samples made with $10 \%$ of recycled rubber, in comparison to the reference concrete, is $36 \%$, while in samples made with $20 \%$ and $30 \%$ of recycled rubber, the decrease of compressive strength is $60 \%$ and $70 \%$, respectively. The flexural strength decrease tested on 28 -day samples made with $10 \%, 20 \%$ and $30 \%$ of recycled rubber, in comparison to the reference concrete, amounts to $20 \%$, $34 \%$, and $55 \%$, respectively.

As for the tests of ultrasonic wave propagation through concrete, it can be observed on the basis of obtained results that the wave velocity in concrete decreases with an increase in the quantity of recycled rubber granulate in concrete, cf. Table 5. Therefore, the reduction of wave velocity for concrete comprising $10 \%$ of rubber aggregate is $5 \%$ if compared to reference concrete, while for concrete comprising $20 \%$ and $30 \%$ of rubber aggregate this reduction is $14 \%$ and $21 \%$ respectively. This demonstrates that rubber granules in concrete are weak spots in its structure, and that they do not contribute to the increase of mechanical characteristics of concrete, as directly demonstrated by the compressive strength and tensile strength test results. It should however be noted that rubber has sound-absorption capabilities,
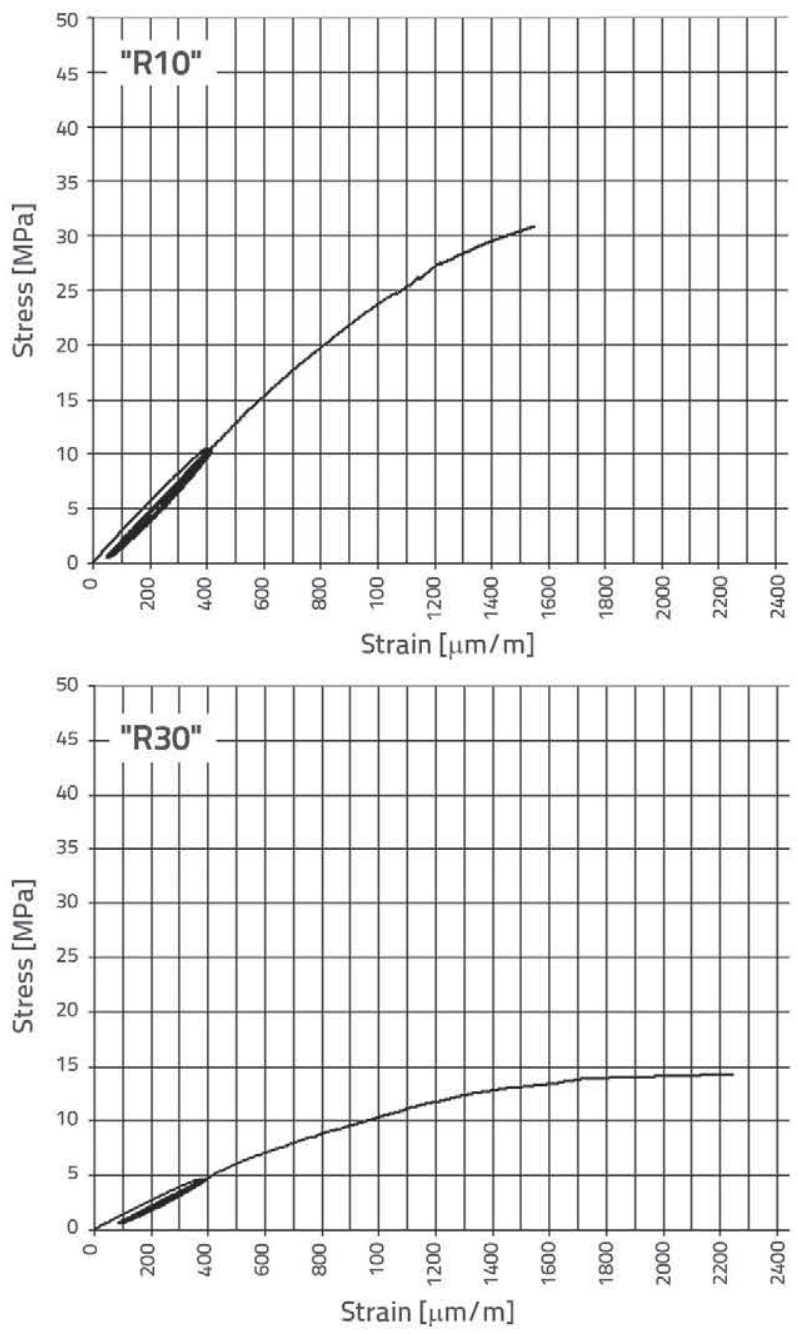
which is one of the reasons for the lower velocity of ultrasonic wave propagation through concrete. The increased content of entrapped air also influenced the reduction of ultrasonic wave propagation through concrete containing rubber granules. According to the data contained in Table 4, the content of entrapped air increases with an increase in rubber granulate content in concrete. Khaloo, Dehestani and Rahmatabadi reached similar conclusions in their paper [42].

The surface hardness test by rebounding hammer exhibited results that are similar to those obtained by the above-mentioned tests, cf. Table 5. The rebound value reduced with an increase of the rubber aggregate content in concrete. The sclerometer rebound number for concrete containing 10, 20, and $30 \%$ of granulated rubber decreased by $8 \%, 21 \%$, and $28 \%$, respectively in comparison with reference concrete. Here it should also be noted that rubber contained in hardened concrete dampens to a certain extent the blows of the hammer, and reduces its rebound number. Mohammed, Azmi and Abdullahi obtained similar results in the paper [43].

Based on comparison of diagrams shown in Figure 5, it can be observed that nonlinearity increases at higher load levels in parallel with an increase in the rubber content percentage, except for the reduction of compressive strength and modulus of elasticity. This results in an increase in ductility of the tested concrete, which is a favourable characteristic in terms of structural capacity (especially for aseismic buildings) [44]. The ductility index (DI) calculated from the equation $\mathrm{Dl}=\varepsilon_{\mathrm{u}} / \varepsilon_{\mathrm{e}}$ based on the ratio of strain at failure to values in elastic zone, at $1 / 3$ of compressive strength, is presented in Figure 6. When the quantity of rubber exceeds $20 \%$, the value of strain exceeds $2 \%$. There is a noticeable curve drop in the elastic area after the quantity of the rubber exceeds $10 \%$. The static elastic modulus of concrete with $10 \%$ of recycled granulated rubber is by $16 \%$ lower when compared to reference concrete, while the static modulus is lower by $46 \%$ and $54 \%$ for concrete with $20 \%$ and $30 \%$ of rubber, respectively.

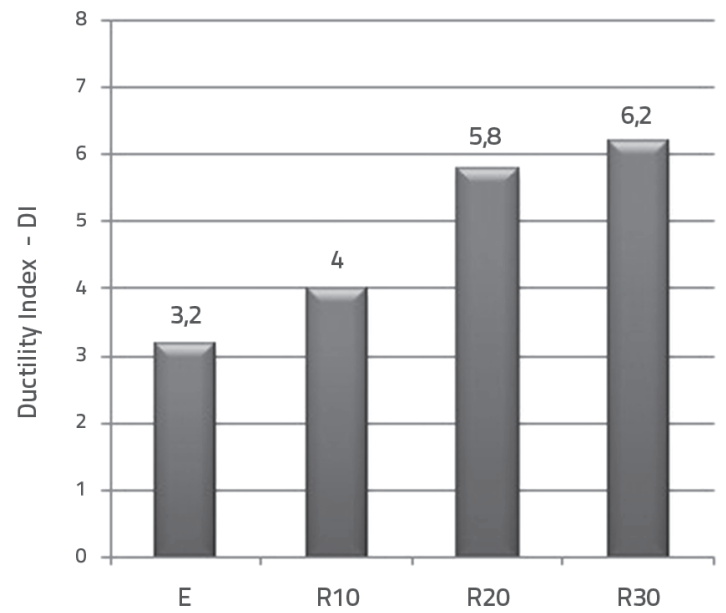

Figure 6. Ductility Index - DI

The analysis of bond strength results obtained by the "pulloff" method, cf. Table 5, shows that bond strength values decrease with an increase in the share of recycled rubber

Table 6. Loss of specimen mass and volume and the abrasion erosion rate

\begin{tabular}{|c|c|c|c|c|c|}
\hline Specimen series & $\begin{array}{c}\text { Mass loss } \Delta \mathrm{m} \\
{[\mathrm{g}]}\end{array}$ & $\begin{array}{c}\mathrm{E}_{\mathrm{R}, \mathrm{m}} \\
{[\mathrm{g} / \mathrm{min}]}\end{array}$ & $\begin{array}{c}\gamma_{\text {hard, conc }} \\
{\left[\mathrm{g} / \mathrm{cm}^{3}\right]}\end{array}$ & $\begin{array}{c}\text { Volume loss } \Delta V \\
{\left[\mathrm{~cm}^{3}\right]}\end{array}$ & $\begin{array}{c}E_{\mathrm{R}, \mathrm{V}} \\
{\left[\mathrm{cm}^{3} / \mathrm{min}^{3}\right]}\end{array}$ \\
\hline $\mathrm{E}$ & 41,4 & 0,3450 & 2,340 & 17,69 & 0,1474 \\
\hline R10 & 36,5 & 0,3042 & 2,135 & 17,10 & 0,1425 \\
\hline R20 & 45,6 & 0,3800 & 2,025 & 22,52 & 0,1877 \\
\hline R30 & 57,7 & 0,4808 & 1,945 & 29,67 & 0,2473 \\
\hline
\end{tabular}
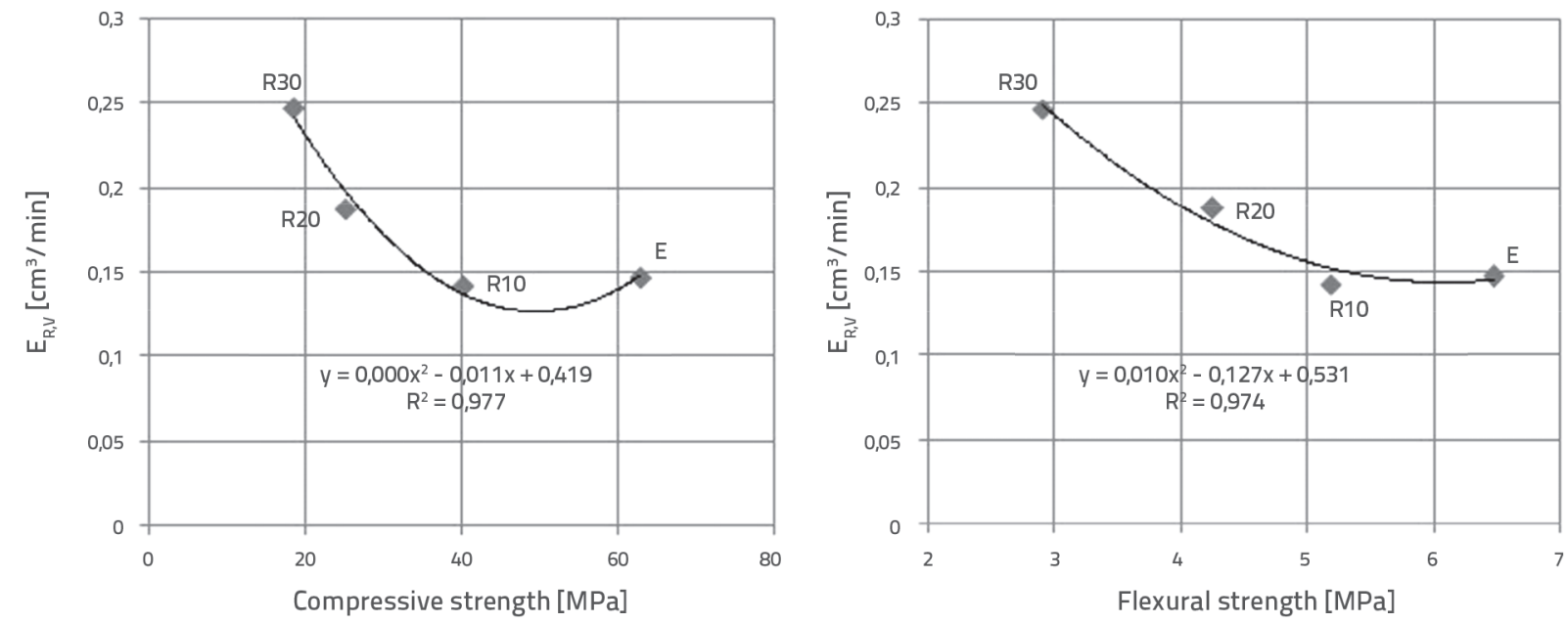

Figure 7. The relationship between compressive strength (left) and flexural strength (right) and abrasion erosion rate 

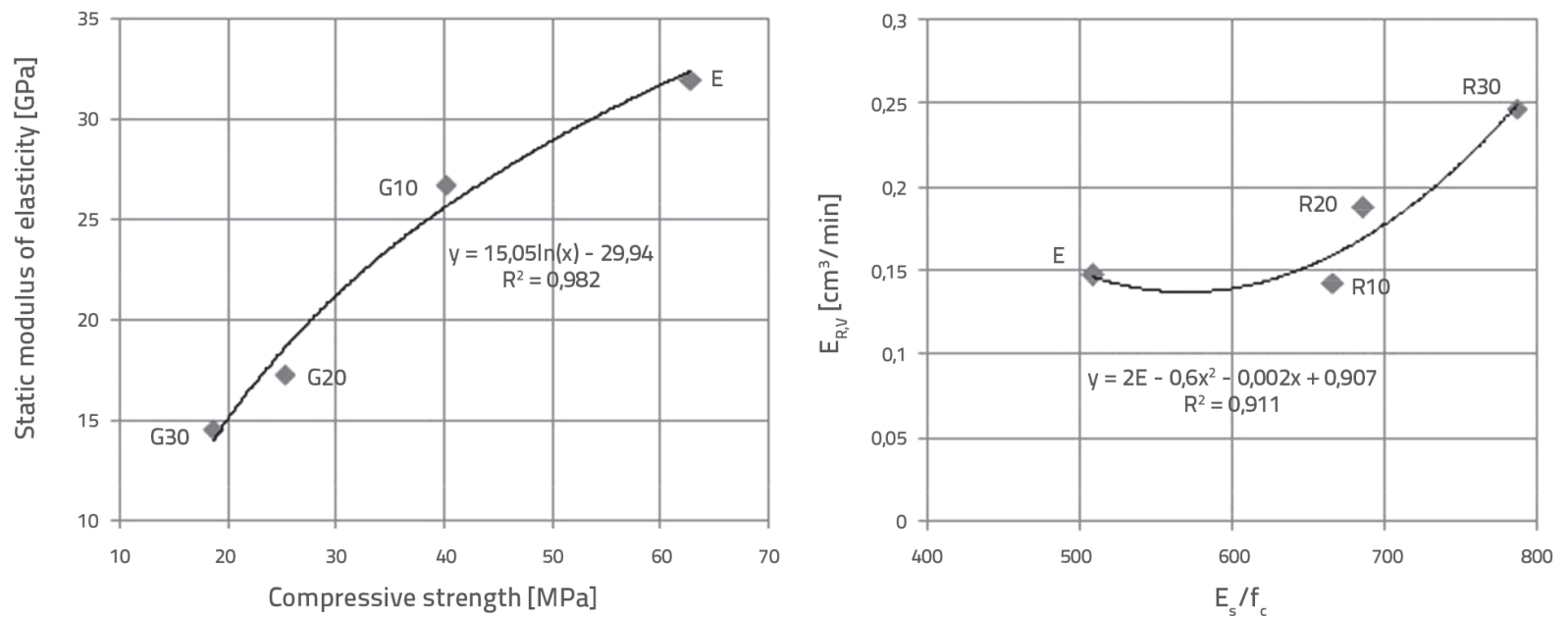

Figure 8. Relationship of compressive strength and static modulus of elasticity (left) and ratio of the static elastic modulus and compressive strength to the abrasion erosion rate by volume (right)

granulate in concrete. The highest value is obtained at the reference sample $(E)$, while the bond strength of the sample with $10 \%$ of recycled granulated rubber (R10) decreased by $15 \%$ with respect to the reference sample. The bond strength of the sample with $20 \%$ of recycled granulated rubber (R20) decreased by $30 \%$ and the bond strength decreased by $51 \%$ for the sample with $30 \%$ of recycled granulated rubber (R30), as compared to reference concrete. During the bond strength testing by the "pull-off" method, the failure in concrete occurred along the cement stone and grains of river stone aggregate, as well as along the contact of the rubber granulate and the cement stone. The basic cause of bond strength reduction obtained by the "pull-off" test on concrete samples containing rubber, as compared to reference samples, is the lower adhesion between the cement stone and rubber granulate, as compared to the adhesion of the cement stone and the river stone aggregate.

As for the abrasion resistance of concrete, the analysis of the abrasion erosion rate by volume, cf. Table 6 , shows that the concrete with $10 \%$ of river aggregate replaced with recycled rubber granulate is better when compared to reference concrete, even though its compressive and flexural strength values are lower than the similar values of the reference concrete. Since it is impossible to test several concrete characteristics on the same sample, the correlation between the hydro-abrasion resistance of concrete and other concrete properties can be made solely on the basis of mean values of test results. In the diagram showing dependence of the abrasion erosion rate by volume and compressive strength, i.e. flexural strength, cf. Figure 7, it can be observed that the concrete containing less than $10 \%$ of the recycled granulated rubber has a higher abrasion resistance, compared to the concrete with the rubber content higher than $10 \%$, and the concrete with no rubber. The correlation curve obtained on the basis of results obtained during this research shows that concrete has the highest hydro-abrasive resistance in the area between "E" and "R10", which should be confirmed by further research.
A very good correlation between the compressive strength of 28-day specimens and static elastic modulus obtained at the same age of concrete was established, cf. Figure 8 (left). The static elastic modulus reduces with the reduction of compressive strength of concrete, as a consequence of the increase of rubber content in concrete. A very good correlation is achieved when the ratio of the static elastic modulus to compressive strength $(\mathrm{Es} / \mathrm{fc}$ ) is calculated and compared with $E_{R, y^{\prime}}$ cf. Figure 8 (right). This correlation shows that concrete will be more resistant to hydro-abrasive action, i.e. that $E_{R, V}$ will be smaller if Es/fc ratio is higher, provided that the share of the recycled granulated rubber in concrete is up to $10 \%$. Concrete with higher $\mathrm{Es} / \mathrm{fc}$ tends to deform elastically when solid water borne particles abrade the concrete surface and, therefore, the loss of concrete mass is smaller [28]. Additional research must be conducted in order to explain this phenomenon in more detail, with the goal of developing a concrete that is permanently durable when exposed to abrasive action. However, as the content of rubber exceeds
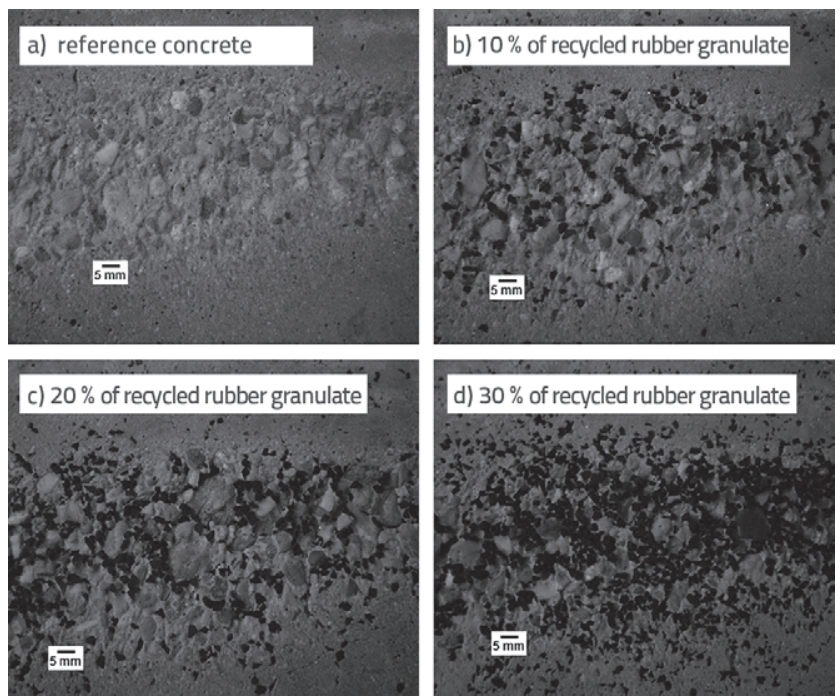

Figure 9. Appearance of concrete samples surfaces after abrasion strength tests 
$10 \%$, ratio Es/fc also increases, i.e. the surface of the concrete becomes more elastic, while the abrasive resistance reduces. In this case, concrete can absorb the impact of water-borne solid particles to a greater extent but, after compensation of the absorption capacity of concrete, less energy is required to chip superficial parts of concrete. This is due to the fact that the bond between the cement stone and aggregate becomes weaker due to an increased concentration of granulated rubber, which is indicated by bond strength results obtained by the pull-off method. It is known that the adhesion of the cement stone and rubber granulate is weaker when compared the adhesion of the cement stone and stone aggregate.

The presence of an optimum quantity of rubber granulates in concrete mixture provides additional elasticity to concrete, dampens the impact of the abrasive matter in water, and thus reduces wear of the concrete surface. However, if greater quantity of rubber material is added, the concrete composite loses its compactness, because the rubber granulate is the weak spot in concrete. Its presence reduces adhesion between the cement stone and coarse aggregate, and prevents the coarse aggregate from participating in the bearing capacity of concrete, which results in concrete failure at the level of cement stone. The worn off surface of the reference concrete is partly smooth due to the regular wear of concrete particles, while in case of recycled rubber samples, this surface is considerably rougher, due to tear of the river aggregate grains and rubber granulate from concrete. The surface appearance of the concrete tested to abrasion is presented in Figure 9.

\section{Conclusion}

The following conclusions can be made on the basis of experimental research results:

- The test procedure and equipment presented in this paper are suitable for practical experimental evaluation of hydroabrasive resistance of concrete subjected to sand/water jet action.

- The concrete with $10 \%$ replacement of fine river aggregate with recycled rubber granulate has a slightly better hydro-abrasive resistance when compared to the reference concrete with no rubber added, even though its compressive and flexural strength values are lower than those of the reference concrete. The hydro-abrasive resistance of concrete reduces if the share of the recycled granulated rubber in concrete is increased beyond $10 \%$,

\section{REFERENCES}

[1] Siddique, R.: Waste Materials and By-Products in Concrete. Scrap Tires, Chapter 4, Springer; 1st. ed., pp. 121-145, 2007.

[2] Kerševicius, V.: Rubber waste - raw materials for building: technical and economical aspects of utilization environmental research, Eng Manag, 3 (21), pp.72-77, 2002.
- Static modulus of elasticity and compressive strength ratio $\left(E_{s} / f\right)$ can be an indicator of hydro-abrasive resistance of concrete. The hydro-abrasion erosion rate by volume $\left(E_{R, V}\right)$ will be smaller if the $E_{s} / f_{c}$ ratio is higher, when the share of the recycled granulated rubber in concrete is up to $10 \%$.

- The replacement of fine river aggregate by recycled granulated rubber caused reduction of compressive strength, flexural strength, bond strength by "pull-off", and static modulus of elasticity. For example at 28 days, the compressive strength decreased by 36 to $70 \%$, flexural strength by 20 to $55 \%$, bond strength by "Pull-off" by 15 to $51 \%$, and static modulus of elasticity by 16 to $54 \%$, depending on the granulated rubber content.

- The ultrasonic wave propagation through concrete, and the rebound number of sclerometer, actually decrease with an increase in the quantity of recycled rubber granulate in concrete. For example, at the age of 28 days, the ultrasonic wave propagation through concrete decreases by $5-21 \%$, and the rebound number decreases by $8-28 \%$ depending on the content of granulated rubber.

- The ductility index (DI) increases with an increase of granulated rubber in concrete. The concrete produced with the recycled granulated rubber enables better energy dissipation and ductility than normal concrete, and could find use in seismic applications. However, the abrupt decrease of compressive strength and static elastic modulus as the amount of granulated rubber in concrete increases, should be taken into account.

- On the basis of results obtained in this research, the best hydro-abrasive resistance should be expected in concrete produced by using about $5 \%$ of granulated rubber instead of fine river stone aggregate. Additional research should be undertaken to prove the resistance of the surface of such concrete to the action of waterborne solid particles.

\section{Acknowledgements}

The work reported in this paper is a part of the investigation conducted within the research project TR 36017 "Utilization of by-products and recycled waste materials in concrete composites in the scope of development of sustainable construction in Serbia: investigation and environmental assessment of possible applications", supported by the Ministry of Science and Technology, Republic of Serbia. This support is gratefully acknowledged.
[3] Ganjian, E., Khorami, M., Maghsoudi, A.A.: Scrap-tyre-rubber replacement for aggregate and filler in concrete, Constr Build Mater, 23, pp.1828-1836, 2009.

[4] Issa, C.A., Salem, G.: Utilization of recycled crumb rubber as fine aggregates in concrete mix design, Constr Build Mater, 42, pp. 48-52, 2013. 
[5] Sukontasukkul, P., Tiamlom, K.: Expansion under water and drying shrinkage of rubberized concrete mixed with crumb rubber with different size, Constr Build Mater, 29, pp. 520-526, 2012.

[6] Al-Tayeb, M.M., Abu Bakar, B.H., Ismail, H., Akil, H.M.: Effect of partial replacement of sand by fine crumb rubber on impact load behavior of concrete beam: experiment and nonlinear dynamic analysis, Mater Struct doi: 10.1617/s11527-012-9974-3, 2012.

[7] Ozbay, E., Lachemi, M., Sevim, U.K.: Compressive strength, abrasion resistance and energy absorption capacity of rubberized concretes with and without slag, Mater Struct, 44, pp.1297-1307, 2011.

[8] Gesoglu, M., Guneyisi, E.: Strenght development and chloride penetration in rubberized concretes with and without silica fume, Mater Struct, 40, pp. 953-964, 2007.

[9] Lakusic, S., Bjegovic, D., Baricevic, A., Haladin, I.: Develompent of high performance concrete for high speed railways, International symposium about research and application of modern achievements in civil engineering in the field of materials and structures, Tara, Serbia, pp. 81 - 88, 2011

[10] Bjegovic, D., Serdar, M., Jelcic Rukavina, M., Baricevic, A.: Study of reinforced-concrete sustainability criteria, Gradevinar 62 (10), pp. 931-940, 2010.

[11] Serdar, M., Baricevic, A., Lakusic, S., Bjegovic, D.: Special purpose concrete product from waste tyre recyclates, Gradevinar 65 (2013) 9, pp. 793-801, 2013.

[12] Najim, K.B., Hall, M.R.: Mechanical and dynamic properties of self-compacting crumb rubber modified concrete, Constr Build Mater, 27, pp. 521-530, 2012

[13] Han, Z., Chunsheng, L., Kombe, T., Thong-On, N. Crumb rubber blend in noise absorption study. Mater Struct, 41, pp. 383-390, 2008.

[14] Graham, J.R.: Erosion of concrete in hydraulic structure, Report by ACl Comm 210, ACl man Pract, Part I, 1998.

[15] ACl 210R-93 - Erosion of concrete in hydraulic Structures

[16] Binici, H., Aksogan, O., Gorur, E. B., Kaplan, H., Bodur, M. N.: Hydroabrasive erosion of concrete incorporating ground blast-furnace slag and ground basaltic pumice. Constr Build Mater, 23, pp. 804-811, 2009.

[17] Lui, Y.W.: Improving the abrasion resistance of hydraulicconcrete containing surface crack by adding silica fume, Constr Build Mater, 21, pp. 972-977, 2007.

[18] Siddique, R., Khatib, J.M.: Abrasion resistance and mechanical properties of high-volume fly ash concrete, Mater Struct, 43, pp. 709-718, 2010.

[19] Choi, S., Bolander, J.E.: A topology measurement method examining hydraulic abrasion of high workability concrete, KSCE Journal of Civil Engineering, 16 (5), pp. 771-778, 2012.

[20] Ristic, N., Grdic, Z., Toplicic-Curcic, G.: Influence of fly ash on the hydroabrasion-erosion resistance on concrete in hydraulic structures, Proceedings of the 12th International Scientific Conference "Planning, design, construction and renewal in the civil engineering", Novi Sad, Serbia, pp. 658-665, 2012.

[21] Horszczaruk, E.K.: Hydro-abrasive erosion of high performance fiber-reinforced concrete, Wear, 267, pp. 110-115, 2009.

[22] Hu, X.G., Momber, A.W., Yin, Y.G.: Hydro-abrasive erosion of steel-fibre reinforced hydraulic concrete, Wear 253, pp. 848-854, 2002.

[23] Hu, X.G., Momber, A.W., Yin, Y., Wang, H., Cui, D.M.: High-speed hydrodynamic wear of steel-fibre reinforced hydraulic concrete, Wear 257, pp. 441-450, 2004
[24] Ristic, N., Grdic, Z., Toplicic-Curcic, G., Despotovic, I.: Hydroabrasive resistance of micro-reinforced concrete with steel and polypropylene fibres, International symposium about research and application of modern achievements in civil engineering in the field of materials and structures, Tara, Serbia, pp. 125 -134., 2011.

[25] Chernov, V., Zlotnikov, H., Shadalov, M.: Structural synthetic fiber-reinforced concrete. Experience with marine applications, Concr Int, 8, pp. 56-61, 2006

[26] Grdic, Z., Curcic, G.T., Ristic, N., Despotovic, I.: Abrasion resistance of concrete micro-reinforced with polypropylene fibers, Constr Build Mater, 27, pp. 305-312, 2012

[27] Toutanji, H.A.: The Use of Rubber Tire Particles in Concrete to Replace Mineral Aggregates, Cem Concr Compos, Vol. 16, pp.135-139, 1996.

[28] Šušteršič, J.: Abrazijsko odporni betoni, 11. slovenski kolokvij o betonih - Gradnja z betoni visokih zmogljivosti, Zbornik gradiv in referatov, Ljubljana, Slovenia, pp. 41-48, 2004.

[29] Yen, T., Hsu, T.H., Lui, Y.W., Chen, S.H.: Influence of class F ash on the abrasion-erosion resistance of high-strength concrete, Constr Build Mater, 21, pp. 458-63, 2007.

[30] Lui, Y..W, Yen, T., Hsu, T.H.: Abrasion erosion of concrete by water-borne sand, Cem Concr Res, 36, pp.1814-20, 2006.

[31] ASTM C 418-98: Standard test method for abrasion resistance of concrete by sandblasting.

[32] Małasiewicz, A.: Test systems for abrasion of hydraulic concrete, Gospodarka Wodna, 4, pp.152-155, 1974.

[33] Misra, A., Finnie, I.: On the size effect in abrasive and erosive wear, Wear 65, pp. 359-373, 1981

[34] ASTM C 944-99: Standard test method for abrasion resistance of concrete or mortar surfaces by the rotating-cutter method.

[35] Nanni, A.: Abrasion resistance of roller compacted concrete, ACI Mater J, 86 (10), pp. 559-565, 1989.

[36] Shi, Z.Q., Chung, D.D.L.: Improving the abrasion resistance of mortary by adding latex and carbon fibers, Cem Concr Res, 27 (8), pp. 1149-1153, 1997

[37] Bania, A.: Bestimmung des Abriebs und der Erosion von Betonen mittels eines Gesteinsstoff-Wassergemisches, Dissertation B, TH Wismar, 248 p., 1989

[38] Haroske, G.: Erosionsverschleiss an Betonoberflachen durch Geschiebetransport, Dissertation, TH Wismar; p. 53-63., 1998.

[39] Horszczaruk, E.: New test method for abrasion erosion of concrete, Proceedings of 15th World Conference on Nondestructive Testing, Roma, Italy, 2000.

[40] ASTM C 1138-97: Standard test method for abrasion resistance of concrete (underwater method).

[41] Momber, A.W., Kovacevic, R.: Accelerated high speed water erosion test for concrete wear debris analysis, Tibol Trans, 39, pp. 943-949, 1996.

[42] Khaloo, A.R., Dehestani, M., Rahmatabadi, R.: Mechanical properties of concrete containing a high volume of tire-rubber particles, Waste Manag, 28, pp. 2472 - 2482, 2008

[43] Mohammed, B.S., Azmi, N.J., Abdullahi, M.: Evaluation of rubbercrete based of ultrasonic pulse velocity and rebound hammer tests, Constr Build Mater, 25, pp. 1388-1397, 2011

[44] Son, K.S., Hajirasouliha, I., Pilakoutas, K.: Strenght and deformability of waste tyre rubber reinforced concrete columns, Constr Build Mater, 25, pp. 218-226, 2011. 